\title{
PREVALENCE OF CELIAC DISEASE AMONG FIRST DEGREE RELATIVES OF BRAZILIAN CELIAC PATIENTS
}

\author{
Patrícia Lopes de ALMEIDA', Lenora GANDOLFI' ${ }^{1,2}$, Inês Cristina MODELLI', \\ Rita de Cássia MARTINS² ${ }^{2}$ Rodrigo Coutinho de ALMEIDA² and Riccardo PRATESI ${ }^{1,2}$
}

\begin{abstract}
Background - Several studies have shown that celiac disease, an autoimmune disorder that occurs in genetically susceptible individuals, is highly prevalent among relatives of celiac patients. Aim - To determine the prevalence of celiac disease in a group of first degree relatives of Brazilian celiac patients. Methods - First degree relatives of celiac patients attending the Brasilia University Hospital Pediatric Gastroenterology Outpatient Clinic or the Celiac Disease Investigation Center, Brasília, DF, Brazil, between March 2001 and November 2004 were invited to undergo serological screening for celiac disease applying the IgA anti-endomysium antibody test (IgA-EMA). All positive IgA-EMA sera underwent a second screening using the IgA anti-tissue transglutaminase antibodies test. Duodenal or small intestinal biopsies were performed in all subjects positive to serological testing. Biopsy samples were classified as type (O) normal, (I) infiltrative, (II) infiltrative hyperplastic, (III) flat destructive, and (IV) atrophic hypoplastic. The final diagnosis was ascertained in subjects showing positive serological tests and a grade I to III small intestinal lesion. Results - Nine new cases of celiac disease were found among the 188 first degree relatives tested (4.8\%). Conclusion - The present study confirms the high prevalence of celiac disease among first degree celiac patients' relatives and reinforces the need of extensive diagnostic screening in this specific group.
\end{abstract}

HEADINGS - Celiac disease, genetics. Brazil.

\section{INTRODUCTION}

Celiac disease (CD) is an immune-mediated disorder that occurs in genetically susceptible individuals in which the ingestion of dietary gluten causes intestinal mucosa inflammation, crypt hyperplasia, and villous atrophy. The disease is associated with human leucocyte antigen (HLA), its primary susceptibility being linked to the presence of HLA-DQ2 and DQ8 haplotypes. However HLA genes contribute with no more than $40 \%$ of the risk, undetermined non-HLA genes probably being the stronger determinant of CD susceptibility ${ }^{(18)}$.

In the last 25 years the emergence of progressively more reliable serological markers, such as anti-gliadin, anti-endomysium ${ }^{(30)}$, and anti-transglutaminase antibodies ${ }^{(29)}$ allowed the precocious diagnosis of atypical or even silent form of the disease and greatly contributed to the widespread acknowledging that the prevalence of $\mathrm{CD}$ was higher than previously thought. Presently CD may be considered a global public health problem and one of the most common chronic auto-immune conditions since its estimated figures in Western countries varies between $1 \%$ and $2.5 \%\left(\%^{(9,19)}\right.$.
In South America CD was considered a rare disease and its prevalence in the general population was mostly unknown. The increased interest in this polymorphic disease during the last decade resulted in several screening studies. In Brazil GANDOLFI et al. ${ }^{(10)}$ reported a prevalence of $1: 681(0.14 \%)$ in presumably healthy blood donors. In the same geographical region PRATESI et al. ${ }^{(27)}$ studying a group of 4,405 adults and children without gastroenterological complaints attending the laboratory of clinical analysis of a large hospital for routine blood testing encountered a prevalence of 1:293 $(0.34 \%)$ of biopsy proven CD patients. Other recent screening studies in Brazil also disclosed expressive results. MELO et al. ${ }^{(22)}$ found a prevalence of 1:273 $(0.36 \%)$ among 3,000 blood donors in Ribeirão Preto city, in the State of São Paulo. PEREIRA et al. ${ }^{(26)}$ screening a population of predominantly European ancestry detected a prevalence of $1: 415(0.24 \%)$. OLIVEIRA et al. ${ }^{(25)}$ in the city of São Paulo, also studying a group of 3,000 potential blood donors found a prevalence of 1:214 $(0.47 \%)$. Expressive results were also obtained by GOMEZ et al. ${ }^{(11)}$ in Argentina. Studying 2,000 adults attending an obligatory prenuptial examination, the authors found a

'Graduate Program in Health Sciences, University of Brasília School of Health Sciences; ${ }^{2}$ Celiac Disease Investigation Center, University of Brasília School of Medicine Brasilia, DF, Brazil.

Correspondence: Dr. Riccardo Pratesi - SQN 212 - Bloco F - apt. 605 - 70864-060 - Brasília, DF, Brazil. E-mail: pratesir@unb.br / riccardop@terra.com.br 
prevalence of $1: 167(0.59 \%)$. Therefore it becomes evident that prevalence of CD in South America is higher than previously thought and is probably underdiagnosed.

Untreated CD predisposes individuals to several complications, some related to malabsorption, such as osteopenia or irondeficient anemia (arising from one or more of iron, folate and vitamin B-12 deficiency), and some associated with the underlying autoimmune process, such as type 1 diabetes and thyroiditis. Other reported complications are delayed puberty, early menopause, infertility, miscarriage, depression, and neurological disorders (epilepsy with cerebral calcifications, ataxia, and peripheral neuropathy). However, the most feared complication is the development of malignancy of the gastrointestinal tract, mainly non-Hodgkin lymphoma that is the most probable reason for the increased mortality in non treated celiac patients ${ }^{(5,21)}$.

$\mathrm{CD}$ is a familial disorder and families with more than one affected member are common. A higher prevalence of $\mathrm{CD}$ among relatives of celiac patients has been demonstrated by several studies $^{(1,2,3,6,8,9,14,15,23,31)}$ fully justifying an active search for undiagnosed $\mathrm{CD}$ among this at-risk group.

Two studies, assessing the prevalence of $\mathrm{CD}$ among relatives of celiac patients have been previously performed in Brazil. The first, by NUNES et al. ${ }^{(24)}$ disclosed a prevalence of $0.8 \%$ among a group of 121 relatives. The main focus of the second study, by KOTZE et al. ${ }^{(16)}$ was to determine specificity and sensitivity of the antiendomysium antibody test performed on cryostatic sections of human umbilical cord, in a group of confirmed celiac patients and their first-degree relatives. Among the 18 serological positive first-degree relatives seven agreed to underwent intestinal biopsy. One of these patients disclosed the characteristic mucosal abnormalities of $\mathrm{CD}$ and the remaining six showed only an increased number of intra-epithelial lymphocytes.

The objective of the present study is consequently to determine the prevalence of $\mathrm{CD}$ in a group of first degree relatives of biopsy-proven $\mathrm{CD}$ patients.

\section{METHODS}

The present study was performed according to the Declaration of Helsinki and approved by the School of Health Sciences Ethics Committee. All subjects were informed about the objectives of the study and the eventual necessity of small intestinal biopsy. Informed consent was obtained from adults and from the parents for their children. First degree relatives of $C D$ patients attending the Brasilia University Hospital Pediatric Gastroenterology out-patient clinic or the Celiac Disease Investigation Center, Brasília, DF, Brazil, between March 2001 and November 2004 were invited to undergo serological screen for CD. The Celiac Disease Center is a weekly walking-in clinic open for diagnosis and follow-up of CD patients, attending both children and adults. The diagnosis of CD patients had been based on the modified European Society of Paediatric Gastroenterology and Nutrition (ESPGAN) criteria $^{(32)}$. All family members were on a gluten-containing diet when serological tests were performed. Each blood samples obtained was centrifuged and the resulting serum was stored at $-20^{\circ}$ until testing. The IgA anti-endomysium antibody indirect immunofluorescent test $(\operatorname{IgA} \text {-EMA })^{(4)}$ was used as first-level screening. Briefly, fixed cryostat sections of the distal portions of primate (Cebus apella) esophagus were used as antigen substrate. Fluorescein-labeled goat antibody to human $\operatorname{IgA}$ was used as a second antibody. All sera were screened at a dilution of $1 / 5$. The presence of characteristic brilliant green network pattern, under fluorescent light microscope, was considered positive. All positive IgAEMA sera underwent a second screening, being tested for the presence of IgA anti-tissue transglutaminase antibodies (IgA-tTG) using an ELISA method (Quanta Lite Human tTG IgA - INOVA Diagnostic Inc, San Diego, CA, USA). Optical density was reported in arbitrary unit as a percentage of the optical density of a pool of positive samples, being 20 units the upper normal limit range (cut-off value), as determined by the manufacturer. Duodenal or small intestinal biopsy was recommended to subjects showing positive results to serological testing. Children underwent small intestinal biopsy with a Watson pediatric capsule, samples being taken at the ligament of Treitz. In adults, biopsy samples were obtained through an endoscopy procedure, using an Olympus gastroscope (Tokyo, Japan) with four to five fragments being taken from the second portion of the duodenum. All biopsy specimens were blindly evaluated by a pathologist and a gastroenterologist and classified according to Marsh classification ${ }^{(20)}$ as type 0, normal. Type I, infiltrative pattern, with normal mucosal architecture with increased infiltration of intraepithelial lymphocytes (IELs). In the present study, a count of 25 IELs/100 epithelial cells was taken as the upper limit of the normal range ${ }^{(13,17)}$. Type II infiltrative hyperplastic, similar to the type I, showing in addition enlargement of the crypts. Type III, flat destructive, characterized by villous atrophy crypt hyperplasia and increased number of IELs. Type IV, atrophic hypoplastic, showing total villous atrophy and hypoplastic cripts. The diagnosis of $\mathrm{CD}$ was finally ascertained in subjects showing positive serological tests and a grade I to III small intestinal lesion.

\section{RESULTS}

One hundred-eighty-eight first degree relatives (113/60\% females and $75 / 40 \%$ males, age range 1 to 75 years, mean age 29.9 years, SD 16.8) out of 307 relatives of $72 \mathrm{CD}$ patients agreed with the screening procedure and, after obtaining informed consent, underwent serological testing. Family members tested included 102 parents ( 42 fathers and 60 mothers, aged 25 to 75 years, median age 36 years), 76 siblings ( 31 brothers and 45 sisters, aged 1 to 75 years, median age 11.5 years), and 10 offspring ( 2 males and 8 females, aged $1-45$ years, median age 9.5 years). Positive IgA-EMA was found in 9 first degree relatives ( 5 sisters, 1 brother and 3 mothers). All nine IgA-EMA positive subjects also showed high levels of IgA-tTG (Table 1) Histological changes characteristic of CD were found in all nine subjects identified by serological testing. 
TABLE 1. Family connection, age, main symptoms, serological and biopsy results of CD patients relatives identified as celiac

\begin{tabular}{|c|c|c|c|c|c|c|}
\hline & $\begin{array}{c}\text { Family } \\
\text { connection }\end{array}$ & $\begin{array}{c}\text { Age } \\
\text { (years) }\end{array}$ & Symptoms & IgA-EMA & IgA-tTG & Biopsy \\
\hline 1 & Sister & 8 & Recurrent abdominal cramps, apathy, decreased appetite, mouth ulcers. & + & $82,8 \mathrm{U}$ & Marsh I \\
\hline 2 & Sister & 9 & Constipation, abdominal distention, bloating. & + & $116,4 \mathrm{U}$ & Marsh III \\
\hline 3 & Sister & 23 & No clinical symptoms. & + & $213,2 \mathrm{U}$ & Marsh III \\
\hline 4 & Sister & 43 & Irritability, apathy, muscle and joint pain, anemia, osteoporosis. & + & $135,5 \mathrm{U}$ & Marsh III \\
\hline 5 & Sister & 75 & Abdominal distension, bloating. & + & - & Marsh III \\
\hline 6 & Brother & 2 & Irritability, abdominal distension. & + & $246,5 \mathrm{U}$ & Marsh III \\
\hline 7 & Mother & 25 & Frequent diarrhea, abdominal distension, bloating, mouth ulcers. & + & $220,2 \mathrm{U}$ & Marsh III \\
\hline 8 & Mother & 30 & Irritability, abdominal distension, bloating, recurrent abdominal cramps, apathy, painful joints. & + & $269,5 \mathrm{U}$ & Marsh III \\
\hline 9 & Mother & 39 & Painful joints, osteoporosis & + & $175 \mathrm{U}$ & Marsh III \\
\hline
\end{tabular}

The prevalence of $\mathrm{CD}$ among the first degree relatives was $9 / 188$ (4.8\%). No positive case was found among the 10 celiac patients' offspring. The main data concerning the nine biopsy proven CD patient are shown in Table 1.

\section{DISCUSSION}

It has long been known that symptomatic $\mathrm{CD}$ is more frequent among relatives of celiac patients. In view of the probable complications of an undiagnosed and untreated $\mathrm{CD}$, it is important to identify family members, mainly those with a silent form of the disease to offer them the benefit of gluten free diet.

In the present study the prevalence of $\mathrm{CD}$ among the first degree relatives was $4.8 \%$. Our results are similar to the result found by FASANO et al. ${ }^{(9)}$ that reported a prevalence of $4.5 \%$ new cases among 205 first degree relatives of celiac patients. Previous screening studies based on serological tests, among first degree relatives of celiac patients, have shown appreciable variation in the prevalence of CD. VITORIA et al. ${ }^{(31)}$ in one of the earliest European studies on the subject observed a prevalence of $2.8 \%$, substantially lower than that observed in subsequent studies, in which the prevalence varied between $4.5 \%^{(9)}$ to $9.5 \%{ }^{(2)}$. These differences could be partially explained by methodological differences in the various studies and by the variability of the genetic background of the distinct population evaluated.

The higher prevalence found among the 76 siblings (7.9\%) than among the 102 parents (2.9\%), although not statistically significant, follows a tendency observed in other studies in which an increased number of affected siblings was also observed $d^{(1,2,3,8,15)}$.

The prevalence of $\mathrm{CD}$ among first-degree relatives dramatically increases when considered only families with two or more cases of $\mathrm{CD}$. In two studies focusing these families the prevalence reported was respectively $9.4 \%^{(23)}$ and $17.2 \%^{(3)}$. In the present work two families showed more than two affected members. Of interest was the diagnosis of $\mathrm{CD}$ in a 3 year-old girl that led to the discovery of $\mathrm{CD}$ in other family members, respectively her mother and two maternal uncles. These multiple $\mathrm{CD}$ cases in the same family are not rare and the risk of $\mathrm{CD}$, although decreased, is still significant in second degree relatives ${ }^{(3)}$.

It is important to stress that a negative result do not exclude the possible future appearance of $\mathrm{CD}$ in a relative of a CD patient. In an interesting 20 year follow-up study,
HOGBERG et al. ${ }^{(14)}$ found two new cases of CD among 120 relatives previously screened and considered negative. Among the siblings tested in the present study a female patient that, at the time of her sister CD diagnosis had tested negative become symptomatic and was diagnosed as celiac 5 years later, disclosing positive serological tests and typical abnormalities on duodenal biopsy. The only way to definitely exclude the risk of future CD would be the HLA genotyping confirming the absence of the predisposing alleles, DQA $1 * 0501$ and DQB $1 * 0201$ (encoding the DQ2 heterodimer), present in approximately $95 \%$ of $\mathrm{CD}$ patients, and DRB $1 * 04$ (associated with the DQ8 heterodimer) found in the remaining $5 \%$. Genotyping, although dependent on a more difficult and expensive technique, would allow the exclusion of a considerable proportion of first degree relatives of $\mathrm{CD}$ probands from further screening for $\mathrm{CD}^{(8)}$.

Among the nine parents diagnosed as celiac only one patient disclosed symptoms that could be considered as part of the classic manifestations of $\mathrm{CD}$. The remaining patients showed atypical form of the disease and one had no specific complaints. Histopathologic examination of eight biopsy samples disclosed typical abnormalities classified as Marsh III. Only a biopsy sample from an 8 year-old girl with both positive IgA-tTG and IgA-EMA tests showed increased number of IELs as single abnormality (infiltrative type of lesion or Marsh I). Increased number of intraepithelial lymphocytes has been considered typical of $\mathrm{CD}^{(12,20)}$, although no necessarily specific since it can be found in other disorders as, for example, small intestinal bacterial overgrowth ${ }^{(28)}$. In this particular child both serological tests were undoubtedly positive and, in addition, her follow-up revealed a progressive quiescence of her symptoms and normalization of both serological tests after being started on gluten free diet.

In conclusion, the present study, utilizing sensitive and specific serological tests, could identify 9 undiagnosed cases of CD among 188 first degree relatives of 72 celiac patients, confirming the high prevalence of the disease in this specific group. This study corroborates other studies on the same subject ${ }^{(1,}$ $2,3,7,14,31)$ and reinforces the fact that relatives of $C D$ patients are a population at high risk of developing gluten intolerance. An extensive screening policy is consequently mandatory in these subjects, especially in members of families in which more than a member is affected. 
Almeida PL, Gandolfi L, Modelli IC, Martins RC, Almeida RC, Pratesi R. Prevalência da doença celíaca em parentes de primeiro grau de pacientes celíacos brasileiros. Arq Gastroenterol. 2008;45(1):69-72.

RESUMO - Racional - Vários estudos têm evidenciado que a doença celíaca, afecção auto-imune que ocorre em indivíduos geneticamente susceptíveis, apresenta prevalência aumentada entre parentes de pacientes celíacos. Objetivo - Determinar a prevalência da doença celíaca em grupo de parentes de primeiro grau de pacientes celíacos brasileiros. Métodos - Parentes de primeiro grau de pacientes celíacos atendidos no Ambulatório de Gastroenterologia Pediátrica do Hospital Universitário de Brasília e no Centro de Pesquisas da Doença Celíaca da Faculdade de Medicina da Universidade de Brasília entre março de 2001 e novembro de 2004 foram testados para detectar a possível presença de anticorpos anti-endomísio (IgA-EMA). Todos os soros IgA-EMA positivos foram submetidos a um segundo teste confirmando a sua positividade sorológica pela presença de anticorpos anti-transglutaminase (IgA-tTG). Biopsias jejunais ou duodenais foram efetuadas em todos os indivíduos com sorologia positiva. As amostras de mucosa foram histologicamente classificadas de acordo com a classificação de Marsh em tipo (0) normal, (I) infiltrativa, (II) hiperplásica infiltrativa, (III) destrutiva plana e (IV) hipoplásica atrófica. O diagnóstico conclusivo foi firmado com base na positividade dos testes sorológicos e na presença de lesões intestinais de grau de I a III. Resultados - Nove novos casos de doença celíaca foram detectados dentre os 188 parentes de primeiro grau de pacientes celíacos (4.8\%). Conclusão - Confirma-se a alta prevalência de doença celíaca entre parentes de primeiro grau de celíacos e reforça-se a necessidade de investigação diagnóstica rotineira deste grupo específico de indivíduos.

DESCRITORES - Doença celíaca, genética. Brasil.

\section{REFERENCES}

1. Bonamico M, Mariani P, Mazzilli MC, Triglione P, Lionetti P, Ferrante P, Picarelli A, Mesturino A, Gemme G, Imperato C. Frequency and clinical pattern of celiac disease among siblings of celiac children. J Pediatr Gastroenterol Nutr. 1996;23:159-63.

2. Bonamico M, Ferri M, Mariani P, Nenna R, Thanasi E, Luparia RP, Picarelli A, Magliocca FM, Mora B, Bardella MT, Verrienti A, Fiore B, Uccini S, Megiorni F, Mazzilli MC, Tiberti C. Serologic and genetic markers of celiac disease: a sequential study in the screening of first degree relatives. J Pediatr Gastroenterol Nutr. 2006;42:150-4.

3. Book L, Zone JJ, Neuhausen SL. Prevalence of celiac disease among relatives of sib pairs with celiac disease in U.S. families. Am J Gastroenterol. 2003;98:377-81.

4. Chorzelski TP, Beutner EH, Sulej J, Tchorzewska H, Jablonska S, Kumar V, Kapuscinska A. IgA antiendomysium-antibody. A new immunological marker of dermatitis herpetiformis and coeliac disease. Br J Dermatol. 1986;87:703-6.

5. Collin P. Should adults be screened for celiac disease? What are the benefits and harm of screening? Gastroenterology. 2005;128(Suppl 1):s104-8.

6. Dube C, Rostom A, Sy R, Cranney A, Saloojee N, Garritty C, Sampson M, Zhang L, Yazdi F, Mamaladze V, Pan I, Macneil J, Mack D, Patel D, Moher D. The prevalence of celiac disease in average-risk and at-risk Western European populations: a systematic review. Gastroenterology. 2005;128(Suppl 1):s57-67.

7. Esteve M, Rosinach M, Fernandez-Banares F, Farre C, Salas A, Alsina M, Vilar P, Abad-Lacruz A, Forne M, Marine M, Santaolalla R, Espinos JC, Viver JM. Spectrum of gluten-sensitive enteropathy in first-degree relatives of patients with coeliac disease: clinical relevance of lymphocytic enteritis. Gut. 2006;55:1739-45.

8. Farré C, Humbert P, Vilar P, Varea V, Aldeguer X, Carnicer J, Carballo M, Gassull MA. Serological markers and HLA-DQ2 haplotype among first-degree relatives of celiac patients. Catalonian Coeliac Disease Study Group. Dig Dis Sci 1999;44:2344-9.

9. Fasano A, Berti I, Gerarduzzi T, Not T, Colletti RB, Drago S, ElitsurY, Green PH, Guandalini S, Hill ID, Pietzak M, Ventura A, Thorpe M, Kryszak D, Fornaroli F, Wasserman SS, Murray JA, Horvath K. Prevalence of celiac disease in at-risk and not-at-risk groups in the United States: a large multicenter study. Arch Intern Med. 2003;163:286-92.

10. Gandolfi L, Pratesi R, Cordoba JC, Tauil PL, Gasparin M, Catassi C. Prevalence of celiac disease among blood donors in Brazil. Am J Gastroenterol. 2000;95:689-92.

11. Gomez JC, Selvaggio GS, Viola M, Pizarro B, la Motta G, de Barrio S, Castelletto R, Echeverria R, Sugai E, Vazquez H, Maurino E, Bai JC. Prevalence of celiac disease in Argentina: screening of an adult population in the La Plata area. Am J Gastroenterol. 2001;96:2700-4.

12. Green PH, Jabri B. Coeliac disease. Lancet. 2003;362:383-91.

13. Hayat M, Cairns A, Dixon MF, O’Mahony S. Quantitation of intraepithelial lymphocytes in human duodenum: what is normal? J Clin Pathol. 2002;55:393-4.

14. Hogberg L, Falth-Magnusson K, Grodzinsky E, Stenhammar L. Familial prevalence of celiac disease: a twenty-year follow-up study. Scand J Gastroenterol. 2003;38:61-5.

15. Korponay-Szabo I, Kovacs J, Lorincz M, Torok E, Goracz G. Families with multiple cases of gluten-sensitive enteropathy. Z Gastroenterol. 1998;36:553-8.

16. Kotze LMS, Utiyama SRR, Nisihara RM, Zeni MPB, Sena MG, Amarante HMS Antiendomysium antibodies in Brazilian patients with celiac disease and their firstdegree relatives. Arq Gastroenterol 2001;38:94-103.

17. Lähdeaho ML, Kaukinen K, Collin P, Ruuska T, Partanen J, Haapala AM, Mäki M. Celiac disease: from inflammation to atrophy: a long-term follow-up study. J Pediatr Gastroenterol Nutr. 2005;41:44-8.
18. Latiano A, Mora B, Bonamico M, Megiorni F, Mazzilli MC, Cucchiara S, Palmieri $\mathrm{O}$, Valvano MR, Annese V. Analysis of candidate genes on chromosomes $5 \mathrm{q}$ and $19 \mathrm{p}$ in celiac disease. J Pediatr Gastroenterol Nutr. 2007;45:180-6.

19. Maki M, Mustalahti K, Kokkonen J, Kulmala P, Haapalahti M, Karttunen T, Ilonen J, Laurila K, Dahlbom I, Hansson T, Hopfl P, Knip M. Prevalence of celiac disease among children in Finland. N Engl J Med 2003;348:2517-24.

20. Marsh M. Gluten, major histocompatibility complex, and the small intestine. Gastroenterology. 1992;102:330-54.

21. Mearin ML, Ivarsson A, Dickey W. Coeliac disease: is it time for mass screening? Best Pract Res Clin Gastroenterol. 2005;19:441-52.

22. Melo SB, Fernandes MI, Peres LC, Troncon LE, Galvao LC. Prevalence and demographic characteristics of celiac disease among blood donors in Ribeirao Preto, State of Sao Paulo, Brazil. Dig Dis Sci. 2006;51:1020-5.

23. Mustalahti K, Sulkanen S, Holopainen P, Laurila K, Collin P, Partanen J, Maki M. Coeliac disease among healthy members of multiple case coeliac disease families. Scand J Gastroenterol. 2002;37:161-5.

24. Nunes CR, Medeiros EH, Leser P, Patrício FR, Wheba J. Dosage of the antibody antigliadin in first degree relatives of celiac patients. Arq Gastroenterol. 1998;35:69-73.

25. Oliveira RP, Sdepanian VL, Barreto JA, Cortez AJ, Carvalho FO, Bordin JO, de Camargo Soares MA, da Silva Patrício FR, Kawakami E, de Morais MB, FagundesNeto U. High prevalence of celiac disease in Brazilian blood donor volunteers based on screening by IgA antitissue transglutaminase antibody. Eur J Gastroenterol Hepatol. 2007;19:43-9.

26. Pereira MA, Ortiz-Agostinho CL, Nishitokukado I, Sato MN, Damiao AO, Alencar ML, Abrantes-Lemos CP, Cancado EL, de Brito T, Ioshii SO, Valarini SB, Sipahi AM. Prevalence of celiac disease in an urban area of Brazil with predominantly European ancestry. World J Gastroenterol. 2006;12:6546-50.

27. Pratesi R, Gandolfi L, Garcia SG, Modelli IC, Lopes de Almeida P, Bocca AL, Catass C. Prevalence of coeliac disease: unexplained age-related variation in the same population. Scand J Gastroenterol. 2003;38:747-50.

28. Remes-Troche JM, Adames K, Castillo-Rodal AI, Ramirez T, Barreto-Zuniga R, Lopez-Vidal Y, Uscanga LF. Intraepithelial gammadelta+ lymphocytes: a comparative study between celiac disease, small intestinal bacterial overgrowth, and irritable bowel syndrome. J Clin Gastroenterol. 2007;41:671-6.

29. Tonutti E, Visentini D, Bizzaro N, Caradonna M, Cerni L, Villalta D, Tozzoli R. French-Italian Laboratory Study Group on Coeliac Disease. The role of antitissue transglutaminase assay for the diagnosis and monitoring of coeliac disease: a FrenchItalian multicentre study. J Clin Pathol. 2003;56:389-93.

30. Unsworth DJ. Serological diagnosis of gluten sensitive enteropathy. J Clin Pathol. 1996;49:704-11.

31. Vitoria JC, Arrieta A, Astigarraga I, Garcia-Masdevall D, Rodriguez-Soriano J. Use of serological markers as a screening test in family members of patients with celiac disease. J Pediatr Gastroenterol Nutr. 1994;19:304-9.

32. Walker-Smith JA, Guandalini S, Schmitz, Shmerling DH, Visakorpi JK. Revised criteria for diagnosis of celiac disease. Report of working group of European Society of Paediatric Gastroenterology and Nutrition. Arch Dis Child. 1990;65:909-11. 